\title{
Tanuljunk emberséget az állatoktól!
}

\author{
Bauer Zita ${ }^{1}$ és Gonda Judit ${ }^{2}$

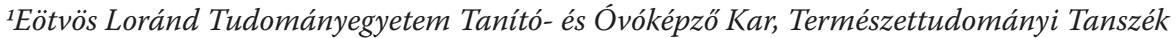 \\ ${ }^{2}$ Scheiber Sándor Gimnázium, Általános Iskola és Kollégium, Budapest
}

\begin{abstract}
Absztrakt
Írásunkat gyakorló tanítóknak és az alsó tagozatos gyermekek nevelésével foglalkozó szakembereknek szánjuk. Tanulmányunkban komplex programot mutatunk be, melyben két tanitó közös munkája eredményeként a szociális kompetenciák fejlesztését, a gyerekek integrációját tüztük ki célul. E tanulmányban az elméleti háttér és a gyakorlati megvalósítás elsö lépéseit szemléltetjük.
\end{abstract}

Kulcsszavak: természet, állatok, állatasszisztált fejlesztés, integráció

\section{A kisgyermek és a természet kapcsolata}

A mai városi ember számára már kevésbé fontos a természet, mint évszázadokkal vagy évezredekkel ezelőtt volt. Az urbanizáció térhódításával élettereinkből kezd kiszorulni a természetes környezet. Igaz ez akkor is, ha olykor-olykor megpróbáljuk visszacsempészni hétköznapjainkba. Szívesen tesszük természetes anyagokkal otthonosabbá lakókörnyezetünket. Szobanövényeinkkel zöldebb környezetet alakítunk ki magunk körül. Ez nyugtató hatással van ránk. Ugyanis mélyen lakozik bennünk ez a természet közelségére való törekvés, amit Wilson (Wilson, 1984) biof íliának nevez. Ez egy belénk kódolt, velünk született, genetikai eredetű igény és érzelmi vonzódás az élet és más élőlények iránt. Az emberiség mentális fejlődéséhez és egészségéhez szükség van arra, hogy az embert más fajokhoz és a természethez is mély, kiegyensúlyozott kapcsolat füzze. Ez a nézőpont felveti az intézményes nevelés felelősségét is a természeti környezet iránti érdeklődés, pozitív irányultság és beállítódás alakulásáért.

Sokszor tapasztalhatjuk, hogy a kisgyermekek inkább szemlélik a világot a természet részeként létező entitásként, mint a felnőttek. $H$ angulatváltozásaik, megérzéseik, vonzódásaik sokkal inkább hasonlítanak a természet közeli vagy konkrétan a természetben élő embertársainkéira. Nincsenek elöítéleteik, rácsodálkoznak a különféle élőlényekre. Azokra is, amelyek mellett egy felnőtt jobb esetben érdeklődés nélkül elmegy, de az is meglehet, hogy undorral, félelemmel figyel rájuk. Miközben a természet, ezen belül az állatvilág a gyermek „természetes” közege. A genetikai eredetű vonzódás fokozottabban jelenik meg náluk, mint a felnőtteknél. 
Mivel a kisgyermek minden cselekedetét, tettét intenzív érzelem kíséri, az állatokkal való kapcsolatot is ez az impulzivitás hatja át. A pozitív érzelmi attitüd megélése jó hatással van közérzetére, így önkéntelenül is törekszik arra, hogy minél többször részese legyen e jó érzésnek, ezért gyakran keresi az állatokkal való kapcsolatokat.

Iskolai munkánk során naponta megtapasztalhatjuk, hogy a kisgyerekek milyen erősen vonzódnak az állatokhoz, foglalkoztatják őket a velük kapcsolatos ismeretek, folyamatosan keresik a miérteket, az állatvilággal és az állatok élőhelyével, életmódjával kapcsolatos ok-okozati összefüggéseket. Ezért is szívesen kerülnek közvetlen kapcsolatba élő állatokkal akár házi kedvencként, akár természeti megfigyelések során, állatkerti foglalkozások keretében. A megismerési folyamatok közben erősödik a vizsgált élőlényekkel kapcsolatos pozitív érzelmi kötődés és felelősségérzet. Ez pedig jó kiindulási alap a tágabb környezet és annak elemei iránti felelősség kialakításához és formálásához (Bihariné, 2011).

\section{Állatasszisztált fejlesztés}

Régóta közismert tény, hogy az idegrendszeri fejlődésben lemaradó, figyelemproblémás gyerekek fejlesztésében jó eredményeket lehet elérni állatok terápiás céllal való bevonásával. Hiszen az állatok érintése, a puha melegségük jó hatással van a kisgyermekekre. Az állattal való foglalkozás rendszerességet, időnként határozottságot követel, ami szintén fejlesztő lehet. Az állat ösztönösen viszonozza a szeretetet bújásával, különféle hangokkal, tekintetével. E visszajelzések hatására az állatasszisztált foglalkozások során igen erős kötődés alakul ki a gyermek és az állat között. A Kaposvári Egyetem munkatársai kutatásuk során rámutattak arra is, hogy az állat asszisztált terápia fontos lehetőség a teljesítményszorongás kezelésében, segít a szorongás oldásában, az önértékelés optimalizálásában is (Takács \& Szalai, 2017). A terápiás foglalkozások jellemző állatai azok az emlősállatok, amelyekkel könnyü kapcsolatot létesíteni (1. kép), ilyenek a nyúl, a kutya vagy a ló. Azonban a kisgyermekek intenzíven érdeklődnek az egzotikus állatok iránt is, bár közvetlen kontaktust nem, vagy csak ritkán tudnak létesíteni, de talán épp ez váltja ki érdeklődésüket. 


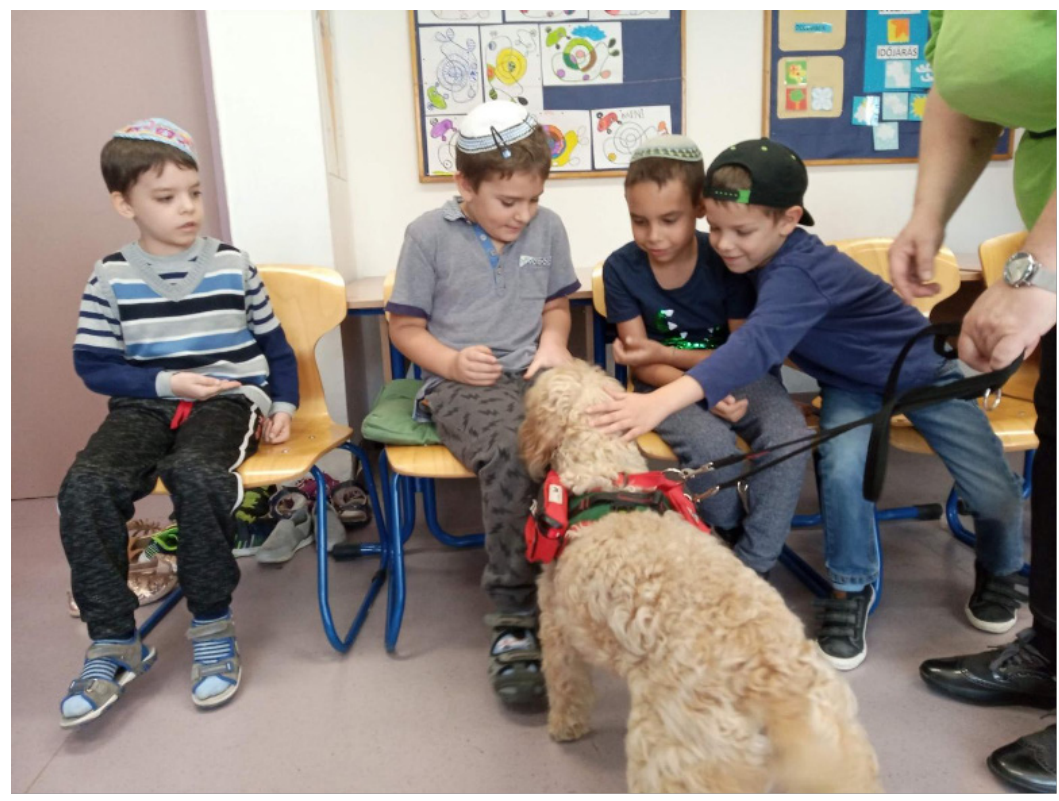

1. kép

Érzékenyitö nap

\section{Az állatvilág témakör feldolgozása a komplex fejlesztés szolgálatában}

Mindennapi munkánk során magunk is megtapasztaltuk, hogy az élő környezet, ezen belül az állatvilág témakör bekapcsolása a tanulási folyamatokba nem csak a nehézségekkel küzdőknek kedvez, hanem minden kisgyermek fejlesztéséhez sokrétű feltételrendszert kínál. Nézzünk néhány példát a legjelentősebbek közül:

\section{A környezettudatosság fejlesztése}

A kisiskolások a világra nyitottak, fogékonyak, érzékenyek. Gondolkodásukat gyakran érzelmeik vezérlik. Érzelmi viszonyulásaik azonban csak a környezetükben átélt személyes élményeikből tudnak kialakulni. Miközben perceptuális úton megfigyelik az állatokat, számos tapasztalatot szereznek azok jellemzőiről. Amennyiben az ismerkedés feszültségmentes és sokszínü, pozitív élmények sorához juttatja a gyermeket, a folyamatban - biztonságban érzi magát. Ez felerősíti pozitív érzelmeit, fejlődik környezettudatos szemléletmódja, a természeti környezet iránti nyitottsága, érzékenysége, felelősségérzete. 
Természetesen a gyermekeknek is vannak kedvenc, szeretett állataik, de vannak olyanok is, amelyektől már iskolába lépéskor okkal vagy ok nélkül irtóznak, esetleg félnek is. Az állatokkal való közvetlen és sikeres kapcsolatépítés segíthet e félelmek feloldásában, gyakran legyőzésében. De hozzájárulhat egy olyan holisztikus szemlélet kialakulásához is, melynek alapja minden élő és élettelen tisztelete.

Nem erőszakolhatjuk a gyerekekre azoknak az állatoknak a szeretetét, melyektől esetleg idegenkednek. De a velük való ismerkedés, az élővilágban betöltött szerepük megláttatása kifejleszti irántuk is azt a tiszteletet, amely hozzájárulhat a közvetlen természeti környezetükhöz való kötődésük erősödéséhez.

A tevékenységek során számos párhuzam vonható az állat-ember és az ember-ember kapcsolat között, így szociális érzékenységüket, egymás iránti felelősségérzetüket is fokozhatjuk. Mivel esetünkben a szociális kompetenciafejlesztés központi témáját az állatok jelentik, az ökológiai területen is segítjük a fenntartható fejlődést. E pedagógiai törekvésünkben kiemelt fontosságot kap a multikulturális perspektívák és eltérő esélyek pedagógiai nézőpontja. Az eltérő kulturális szokásokkal, más hagyományokkal, eltérő társadalmi-gazdasági háttérrel rendelkező gyerekek/fiatalok számára ugyanis kiemelt fontosságú, hogy azonos esélyt teremtve biztosítsuk a szükséges differenciált képzésüket és képességfejlesztésüket.

\section{A problémamegoldó- gondolkodás fejlesztése}

Ha tanítványainkat problémák megoldására szeretnénk nevelni, vagyis tudásrendszereiket arra a szintre szeretnénk fejleszteni, hogy képesek legyenek a valós életben felmerülő problémák megoldására, illetve a problémamegoldással kapcsolatos általános tudásukat is fejleszteni szeretnénk, akkor elsősorban az iskola falain kívül végzett munka kínál kiváló feltételeket. A tantermi folyamatokban megfogalmazható problémák ugyanis bizonyos mértékig műviek. Bár megpróbálhatunk maximálisan életszerü kontextusokat létrehozni, például természetsarok kialakításával, a leghatékonyabb mégis az, ha a saját élőhelyükön figyeltetjük meg az élőlényeket. A tanteremben kevésbé nyílik lehetőség a problémák önálló felismerésére, megfogalmazására, mert az esetek nagy részében maga a pedagógus fogalmazza meg a tanulmányozni, megoldani kívánt problémát. Az iskola falain kívül történő váratlan helyzetek valósak. Előállásuk esetén nagy valószínűséggel következik be, hogy a tanulók, a csoportok önállóan veszik észre a megoldandó problémákat, fogalmazzák meg azokat, s önállóan törekednek a megoldásukra.

Egy kirándulás megszervezése során gondosan eltervezhetjük, hogy mire, milyen összefüggések megfigyelésére szeretnénk tanítványaink figyelmét felhívni. A legértékesebb kérdések azonban mégis azok lesznek, amelyek a helyszínen a gyerekek gondolkodásában születnek meg. Nem készülhetünk fel például az olyan helyzet megoldására, mint amikor földön hánykolódó madárfiókával találkozunk. Kiesett a fészekből? Vagy kidobták? Ha kidobták, vajon miért? Mit 
tegyünk, ha sérült, beteg madarat, vagy fészkéből kiesett madárfiókát találunk? Fel lehet nevelni otthon egy kismadarat? Hogyan gondoskodjunk róla? És még számtalan kérdést tehetnénk fel, de ezek nagy része csak egy valódi, aktuális problémahelyzet megtapasztalásakor születhet meg (Gonda, 2014).

Az élő környezet, az állatok viselkedésének természetes élethelyzetekben történő megfigyelése szolgáltat olyan helyzeteket, amelyekben keresnünk lehet az ok-okozati összefüggéseket, melyekből következtetéseket tudunk levonni, valós problémahelyzeteket oldhatunk meg.

\section{Tehetséggondozás}

A tehetséggondozás során négy fö célt kell szem előtt tartanunk, amelyeknek különböző hangsúllyal, de folyamatosan jelen kell lenniük a fejlesztés folyamatában.

A tehetséges gyerekek nagyon sokszor átlagon felüli logikával, absztrakciós képességekkel rendelkeznek és általában érdeklődnek a világ dolgai iránt. Az érdeklődésüket könnyü felkelteni, ha a téma megannyi rejtély megválaszolására, összefüggés feltárására ad lehetőséget. Az állatvilág megismeréséhez kapcsolható foglalkozások számos alkalmat kínálnak arra, hogy fejleszszük a tehetséges gyermek amúgy is különösen erôs oldalát.

De egy-egy természeti, etológiai megfigyelés próbára teszi a monotónia türést, továbbá fegyelmet, kitartást követel. Az állatokkal való kapcsolatfelvételhez empátiára és türelemre van szükség. Sok kisgyereknek ezt is tanulnia kell. Ez pedig fejleszti a tehetséges gyermek tehetséggel összefüggö gyengébb területeit.

Sok érdeklődő, tehetséges kisgyermeknek alkalomadtán tudatosan kell megálljt parancsolni. Időnként ki kell őket zökkenteni a napi gondolatmenetből, akár az érdeklődésük középpontjában álló problémák megoldásából. Mi lehetne pihentetőbb, mint egy erdei séta, madárfütty hallgatása vagy szarvasbogár nézegetése? De egy kedves háziállat simogatása a relaxációt is szolgálhatja, ezáltal a tehetséggondozás egyik figyelemreméltó célját valósítja meg.

A tehetséggondozás negyedik célja a légkörjavitás. Már szóltunk róla, hogy az állatasszisztált foglalkozások oldják a szorongást, ezáltal e célunkat is szolgálják. Az a felismerés pedig, amikor a hasonló érdeklődésű gyerekek találnak egymásra témánk kapcsán, a közösségfejlesztés szempontjából is igen üdvözítő lehetőség.

\section{A szociális kompetenciafejlesztés, integráció elösegítése}

2017-ben több szempontból is érdekes EU-s projekt indult a Fővárosi Állat- és Növénykert, a Rogers Személyközpontú Oktatásért Alapítvány, a „Milvus Csoport" Madártani és Természetvédelmi Egyesület (Románia) és a TANDEM (Szlovákia) együttmüködésével a „Learning Humanity from Animals” - LEHUA (avagy Tanuljunk emberséget az állatoktól!) címmel. A három éven át tartó projekt fókuszába az ember-állat interakciók kerültek. A résztvevők a rra keresték a 
választ, hogy az állatokkal való kapcsolódás hogyan tud hozzájárulni az intra- és interperszonális képességek kibontakozásához, az empátia, az önreflexió, a reziliencia, és a megküzdőképesség fejlesztéséhez. A munkacsoport által kidolgozott programok a 13-29 éves korosztály számára készültek.

A „Tanuljunk emberséget az állatoktól!” programot az alsó tagozatos gyermekek tanításához, fejlesztéséhez adaptáljuk, beépítve kutatási eredményeit a nevelő-oktató munkánk folyamatába. A program játékainak segítségével különösen jól fejleszthetők a szociális kompetenciák, melyek támogatják problémás tanítványaink sikeres iskolai integrációját is.

\section{A „Tanuljunk emberséget az állatoktól!” program a sikeres integráció szolgálatában}

A program iskolai adaptálásával és kisiskolás tanítványaink nevelésébe történő bevezetésével elsősorban a szociális kompetenciák fejlesztése a célunk, hiszen ezek optimális szintje a sikeres integráció alapvető feltétele. Sokéves gyakorlati tapasztalatunk szerint az integrációs folyamatnak kettős célja van: részint a közösséget kell alkalmassá tenni a befogadásra, részint az integrálandó személyt kell alkalmassá tenni arra, hogy elfogadható legyen a társak számára.

Ezért egyidejűleg és párhuzamosan kell fejlesztenünk az egyén szociális kompetenciáit és alakítanunk a befogadó közösséget. Így a programunkban célokként (Zsolnai Anikó és Kasik László nyomán) az alábbi területek fejlesztését tűztük ki nyomatékosan:

- a szociálisérdek-érvényesítő képességek (együttmüködés, segítés, versengés, vezetés);

- az érzelmi képességek (érzelmek felismerésének, kifejezésének, megértésének és szabályozásának képessége);

- a szociálisprobléma-megoldó képesség (problémaorientációs és problémamegoldási képesség);

- a megküzdési stratégiák (a proszociális és agresszív viselkedésben szerepet játszó, érzelmi és szociális készségekkel összekapcsolódó megküzdési formák);

- szociális kommunikáció.

A felsorolt összetevők a nemzetközi vizsgálatok (például Grusec \& Hastings, 2007; Forgas \& Fitness, 2008) eredményei szerint külön-külön, s egymással való kölcsönhatásuk miatt is nagyon fontos szerepet játszanak az egyén és a környezete számára. Egyaránt hatékonyak a kapcsolatok kialakításában és kezelésében, a társadalmi szabályokhoz, normákhoz és értékekhez való alkalmazkodásban, illetve ezek minél tudatosabb alakításában.

A „Tanuljunk emberséget az állatoktól!” program szervesen illeszkedik a mindennapi pedagógiai gyakorlathoz.

Alkalmazásához mindenekelőtt meg kell ismerkednünk a csoport összetételével, annak szokásrendjével, hagyományaival, a csoporton belüli kap- 
csolatrendszerrel. Iskolakezdéskor vagy új tanulócsoport átvételekor ezek hiányosságaiból kell kiindulnunk céljaink és feladataink meghatározásához. Csak ezek ismeretében építhetjük fel fejlesztési tervünket mind a közösség, mind pedig az egyén szintjére. E „klasszikus” tervezési folyamat gyakorlati megvalósulását, gazdagítja a “Tanuljunk emberséget az állatoktól!" program.

Az alábbiakban az integrációs folyamat algoritmusát figyelhetjük meg. (1. ábra)

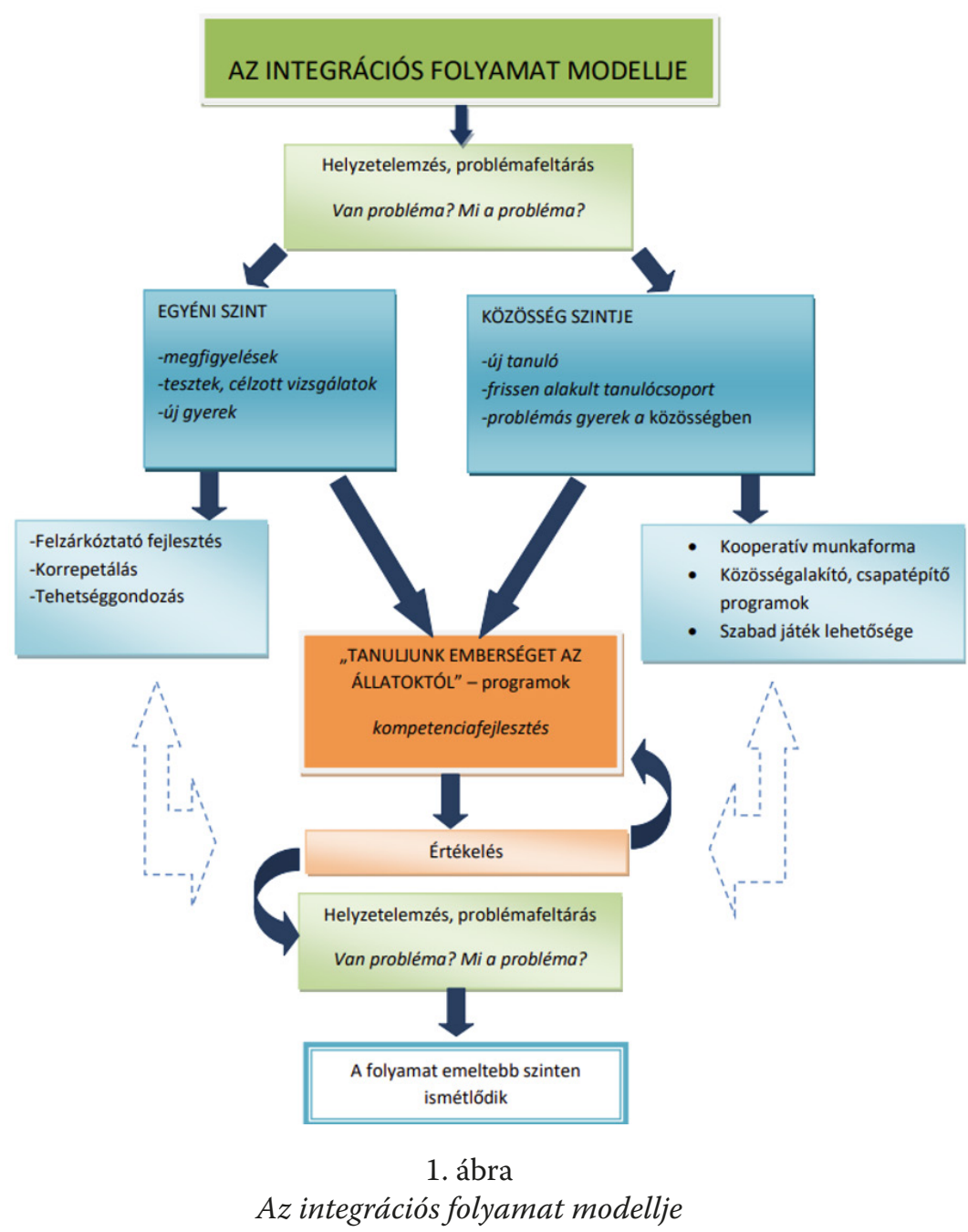




\section{A program domináns tevékenységei, módszerei}

Élő állatok és a közvetlen természeti környezet megfigyelése; az egyes állatokkal kapcsolatos valós tapasztalatokra épülő ismeretszerzés

A természeti környezettel a gyerekek változatos módon ismerkedhetnek. A gyerekek közvetlen környezetébe (közeli park, utca, iskolakert) rendszeresen szervezzünk megfigyeléseket célzó sétákat. Fontos ugyanis, hogy jól ismerjék azt a környezetet, amelyben élnek. Milyen emlősök, madarak, rovarok találhatók ott? Milyen természeti hangok figyelhetők meg? Hogyan változik a környezetünk az évszakok változásával?

Álljon itt egy példa, mennyi érdekes kérdést vetett fel például az egyik sétánk, amelyet ilyen céllal szerveztünk:

- "Keress és fényképezz le:

- ...valamit, ami a Nap felé nyúlik!

- ... valamit, ami elrejti a Napot!

- ...valamit, ami felhővé válhat!

- ...valamit, ami megmutatja, ha fúj a szél!

- ...valamit, ami az eső után jön létre!

- ...egy olyan állattal/állatokkal kapcsolatos jelenséget, amely a hagyományok szerint előre jelzi az időjárást!

- ...egy zivatar átvészelésére alkalmas helyet!

- ...egy olyan helyet, ahol jó hüsölni!

- ...tollakat!

- ...egy magot, amit elfújt a szél!

- ...valamiből kereken 100 darabot!

- ...vadgesztenye leveleket!

- ...természetes úton létrejött faodút!

- ...madárfészek építéséhez alkalmas anyagot!

- ...állatok jelenlétére utaló jeleket!

- ...hangyabolyt!

- ...három különböző magot!

- ...valami kereket!

- ...valami hegyeset!

- ...öt darab szemetet, amit emberek dobtak el!

- ...valamit, ami tökéletesen egyenes!

- ...valami gyönyörüt!

- ...valamit, aminek nincs szerepe a természetben!*

- ...valamit, amibe bele van harapva! (De ne te harapj bele!)

- ...valamit, ami hangokat ad ki!

- ...valami fehéret!

- ...valamit, ami fontos a természetben!*

- ...valamit, amiről azt gondolod, hogy hasonlít rád!

- ...valami puhát! 


\section{- ...egy nagy mosolyt!"}

"ez egy beugratós pont, hiszen azokon a dolgokon kívül, amit emberek találtak ki és helyeztek el, mindennek megvan a maga szerepe a természetben.

Ideális esetben nagyon hasznos, ha az osztályteremben élő állatokkal, növényekkel, természetben található "kincsekkel”, például madárfészekkel, tojáshéjakkal, tollakkal természetsarkot tudunk kialakítani. A gyerekeknek nagy élmény például, ha szünetekben kivehetik, simogathatják az osztály hörcsögét, miközben azt is megtapasztalják, megtanulják, hogy hogyan gondoskodjanak egy kisállatról. Végigkövethetik egy állat életét a születéstől az elpusztulásig, közben pedig kedvezően alakul felelősségérzetük, empátiájuk.

Az élő állatok megfigyelésének egy speciális módja, hogy folyamatosan részt veszünk a Fővárosi Állat- és Növénykert zoopedagógiai foglalkozása$i n$. Itt olyan állatokkal is találkozunk, amelyekkel ritkábban van lehetőségük megismerkedni. Megérinthetünk "nem-szeretem" állatokat is, ami remekül fejleszti a gyermekek érzelmi viszonyulásait.

Ezen foglalkozások anyagába olyan információkat is csempészünk, amelyekhez egyszerủ állatkerti látogatóként nem juthatnának. Nagy élmény találkozni például egy téli álmot alvó pelével, agámát és kígyót simogatni, vagy megfigyelni, hogy valóban ezer lába van-e az ezerlábúnak.

Az állatkerti foglalkozások alkalmával nagyon sok kérdés fogalmazódik meg a gyerekekben, számos ok-okozati összefüggésre derülhet fény. Megfigyelhető az is, hogy milyen az együttműködés az állatok között. A családi szerepek alakulásának tanulmányozása egyébként a szociális érdekérvényesítő képességek fejlődésének kiváló terepe.
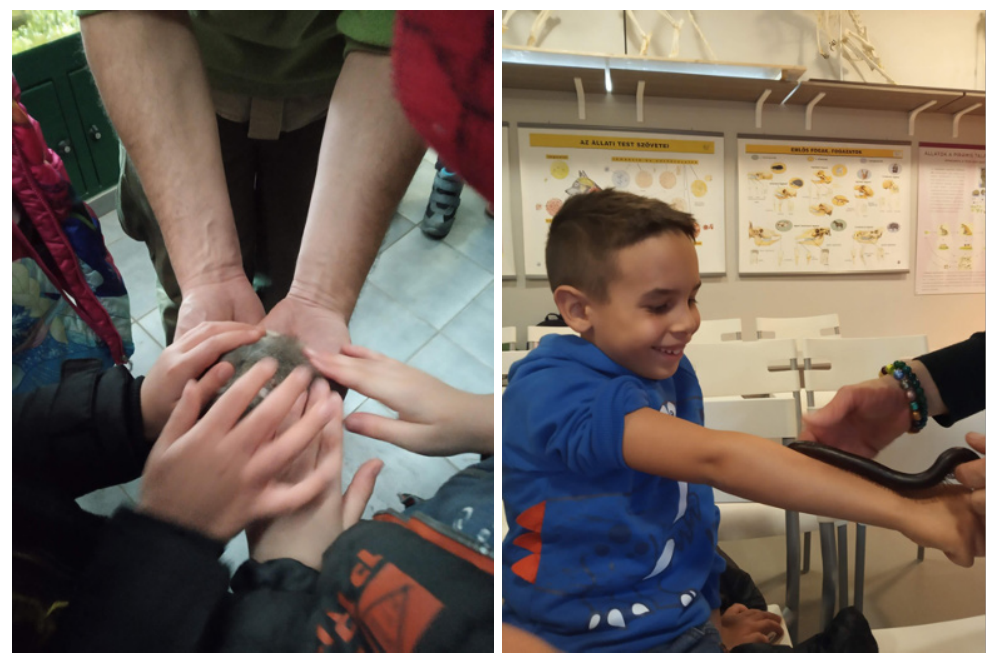

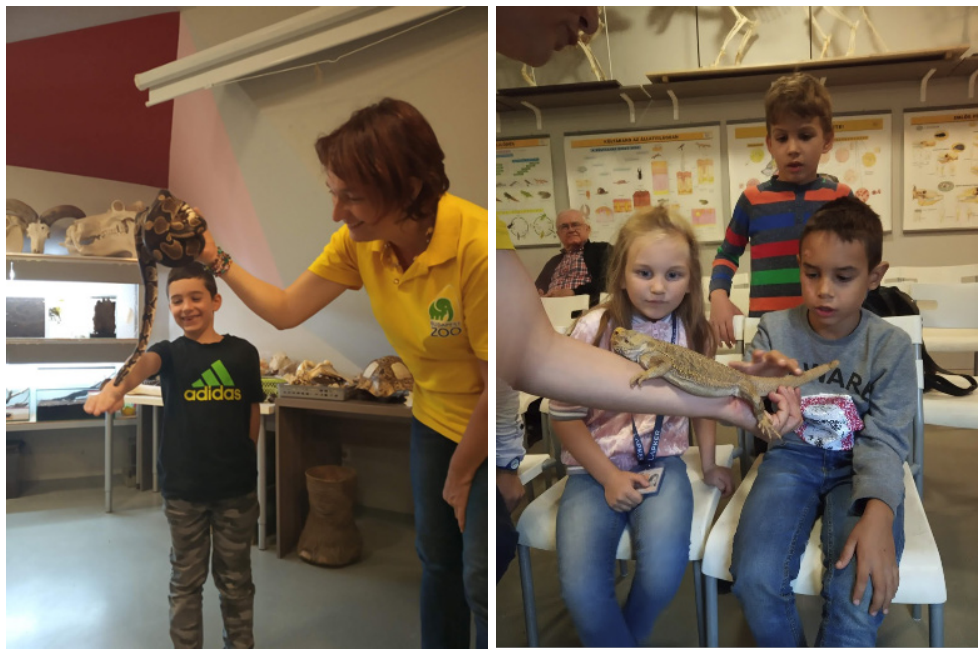

2-5. kép

Állatsimogatás

\section{Szituációs játékok}

Játékaink által a gyerekek ismeretei belsővé válnak, interiorizálódnak. A tanulók maguk élik át azokat a helyzeteket, amelyeket az állatvilág megfigyelése során megtapasztaltak, megtanultak. Például azt, hogyan tájékozódik egy denevér, ha csak az ultrahangokat érzékelheti, vagy miért válik bizalmatlanná az orrszarvú, ha nincs megfelelő térlátása. 

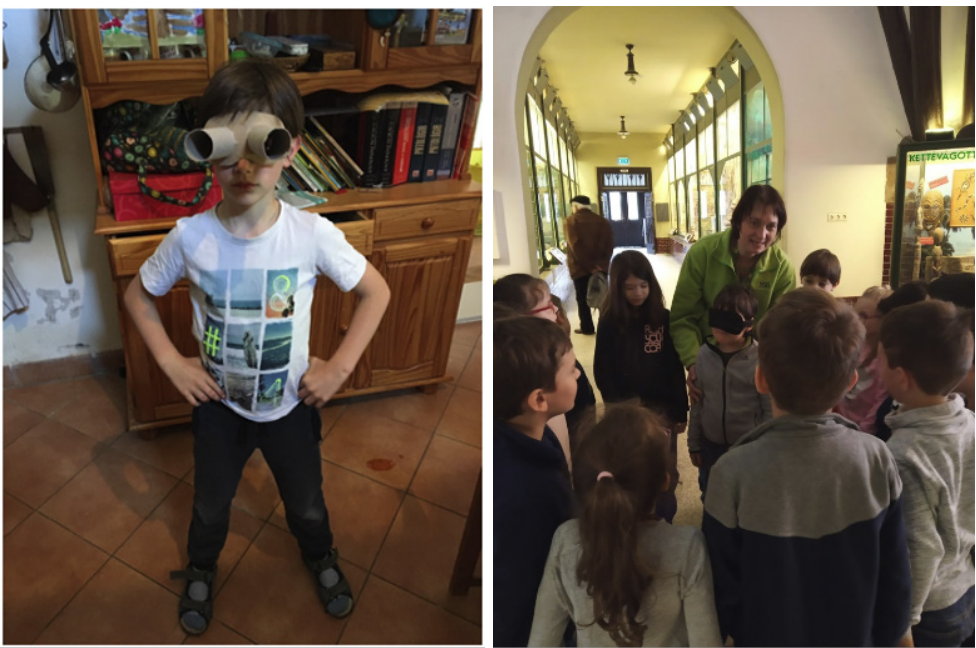

6-7. kép

Ilyen lenne orrszarvúnak vagy denevérnek lenni

A játékot kísérő pozitív érzelmi hangulat által még jobban rögzülnek a tapasztaltak.

Az állatkerti megfigyelésen alapuló szerepjátékokkal, a testtartás, a gesztusok, a mimika megfigyelésével, a szemkontaktus jelentésének értelmezésével, utánzásokkal a szociális kommunikációt fejlesztjük.

Szövegértés-szövegalkotás kompetenciaterülethez kapcsolódó olvasmányok feldolgozása

Egy-egy téma feldolgozásához használjunk irodalmi élményt. Az állatos mesék, versek, regényrészletek, elbeszélések segítik a gyerekek egy-egy állattal történő azonosulását, ezáltal pozitív irányban fejlődik beleérző képességük, empátiás készségük.

A gyerekek szívesen játszanak olyan játékot, amelyben a mese egy szereplöjének "bőrébe bújhatnak": mondaniuk kell magukról egy olyan állítást, amelyröl a többieknek ki kell találniuk, hogy ki lehet ő. A szociális problémamegoldó képesség fejlesztése céljából nagy jelentősége van ezeknek a szempontváltós játékoknak.

A példaként itt bemutatott gyakorlatok nem direkt tanulási szituációkban fejlesztik a szociális kompetenciákat, hanem folyamatosan mélyítik az olyan alapvető fontosságú összetevőket, mint a személyközi viselkedés, az önmagunkkal szembeni felelős viselkedés, a feladattudat vagy a környezettudatos magatartás. 
104

\section{Tantárgyi integráció}

Szélesítve ezt a témakört az iskolai élet minden percét úgy szervezzük, hogy - a tantárgyakat integrálva - a foglalkozásokat áthassa a környezet szeretetének gondolata, a környezet iránti érzékenység, a környezettudatosság szemlélete.

Az alábbiakban bemutatunk egy olyan komplex tanórai tanulási folyamattervet, mellyel szemléltetni szeretnénk, hogy a különböző tantárgyak miként támogathatják egymást a közös cél, a szociális kompetencia fejlesztés megvalósulásában. 


\section{Komplex szemléletü óraterv}

Tanító: Bauer Zita - Gonda Judit

A tanítás ideje: 2020. 02.13.

A tanítás helye: Scheiber Sándor Gimnázium, Általános Iskola és Kollégium Osztály: 1.a osztály

Tantárgy: komplex óra

Témakör: Tanuljunk emberséget az állatoktól!

Téma: Valóságban megfigyelhető állat tulajdonságai, élőhelye és életmódja

Tananyag: A csiga

Domináns didaktikai feladat: Új ismeret feldolgozása

\section{Fejlesztési célok, feladatok:}

\section{Tanulási képességek fejlesztése}

- Megfigyelőképesség fejlesztése a közönséges achátcsiga érzékelhető tulajdonságainak, a terrárium berendezésének, továbbá a szépia anyagának megfigyelésével.

- Leíró képesség fejlesztése a csigákról tanult ismeretek felelevenítésével, asszociációs játékkal, valamint a közönséges achátcsiga érzékelhető tulajdonságainak, a terrárium berendezésének, továbbá a szépia anyagának megfigyelése közben szerzett tapasztalatok megfogalmazásával.

- Azonosító - megkülönböztető képesség fejlesztése a közönséges achátcsiga és más csigák (vízi és szárazföldi) érzékelhető tulajdonságainak, valamint a szépia és a csigaház anyagának összehasonlításával.

- Divergens gondolkodás fejlesztése asszociációs játékkal.

- Ok-okozati összefüggések meglátásának képessége a szépia anyagának és a csigaház anyagának megfigyelésével.

\section{Szociális kompetenciák fejlesztése:}

- Proszociális megküzdési stratégia fejlesztése azáltal, hogy egy másfajta élőlény, egy állat helyébe képzelik a gyerekek magukat.

- Az érzelmi viszonyulások fejlesztése „nem-szeretem” állatok érintésével, pozitív tapasztalatok gyüjtésével.

- Fenntarthatóságra nevelés a csigákhoz kötődő pozitív attitűd fejlesztésével.

- A kommunikációs képesség fejlesztése érvek megfogalmazásával, társak meggyőzésével. (1. táblázat) 
1. táblázat

Óravázlat

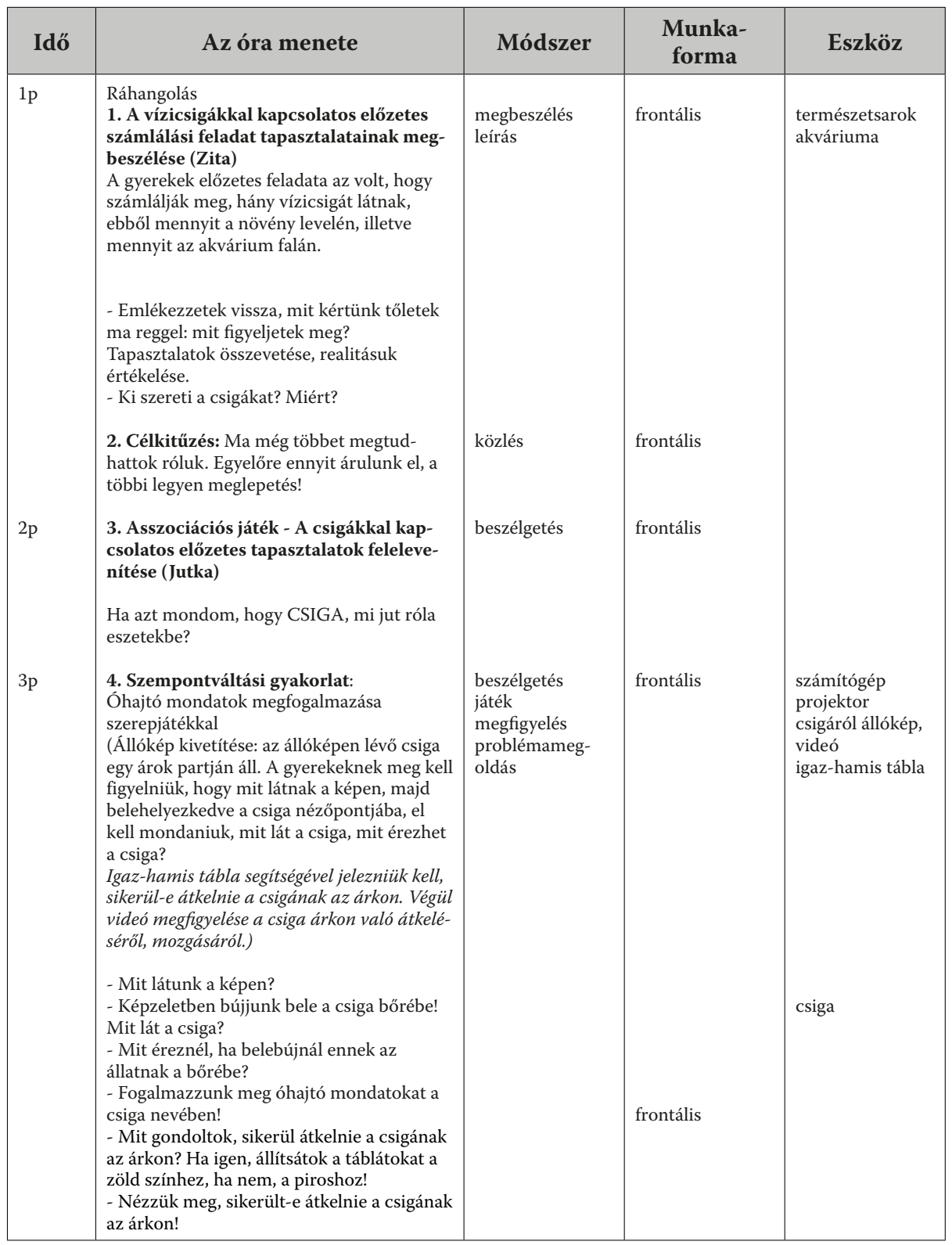




\begin{tabular}{|c|c|c|c|c|}
\hline $4 p$ & 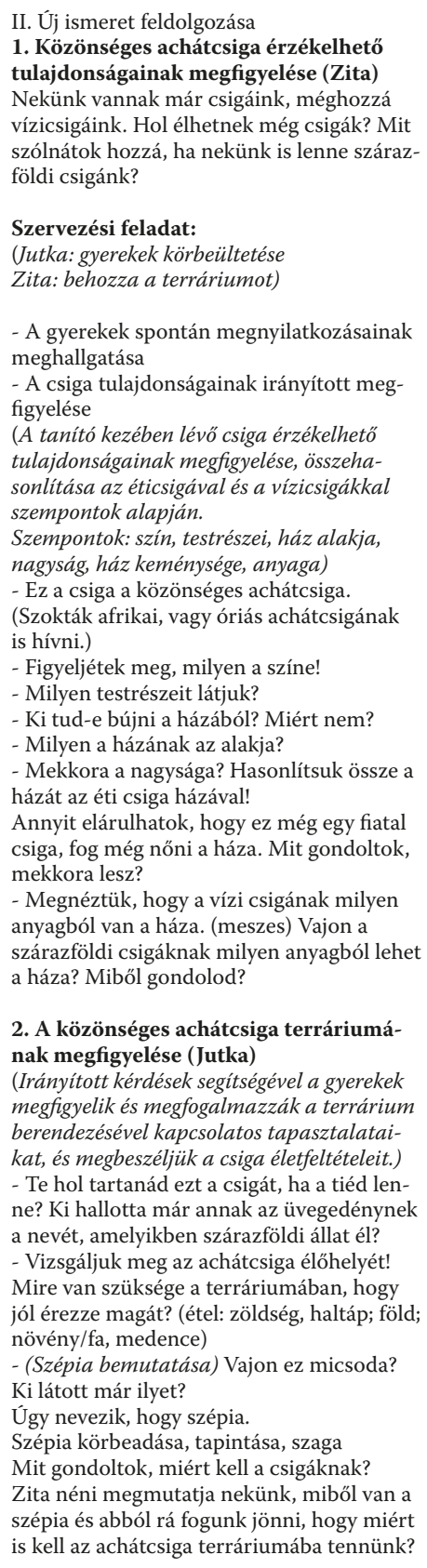 & $\begin{array}{l}\text { megfigyelés } \\
\text { leírás } \\
\text { megbeszélés } \\
\text { szemléltetés } \\
\text { problémafelvetés }\end{array}$ & frontális & $\begin{array}{l}\text { csiga, terrárium, } \\
\text { szépia }\end{array}$ \\
\hline
\end{tabular}




\begin{tabular}{|c|c|c|c|c|}
\hline $12 p$ & 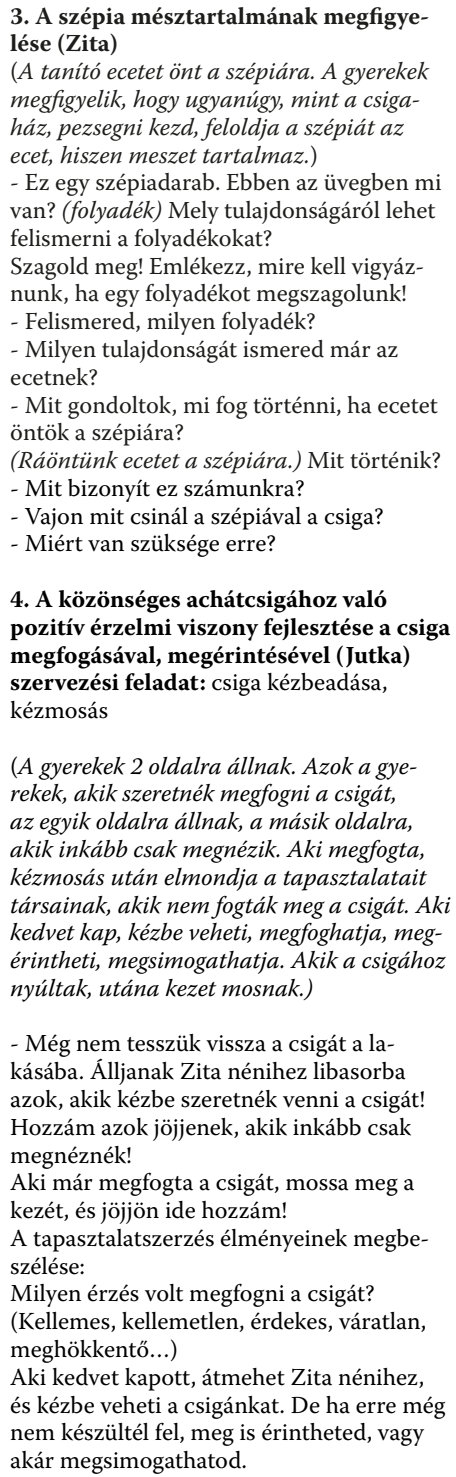 & $\begin{array}{l}\text { tevékenykedtetés } \\
\text { leírás } \\
\text { megbeszélés } \\
\text { szókincsfejlesztés } \\
\text { beszélgetés }\end{array}$ & $\begin{array}{l}\text { frontálisan irá- } \\
\text { nyított egyéni }\end{array}$ & $\begin{array}{l}\text { szépia, } \\
\text { Petri-csésze, ecet }\end{array}$ \\
\hline
\end{tabular}




\begin{tabular}{|c|c|c|c|c|}
\hline $3 p$ & $\begin{array}{l}\text { 5. Párhuzam keresése az állat és az em- } \\
\text { ber viselkedése között a } \\
\text { „bebújik a csigaházba” szóláson keresz- } \\
\text { tül } \\
\text { (A tanító „megijeszti” a csigát. A gyerekekkel } \\
\text { megbeszéljük, mit jelenthet az a mondás, } \\
\text { hogy valaki „bebújik a csigaházba”? Ezután } \\
\text { a gyerekek olyan tulajdonságokat sorolnak } \\
\text { fel, amelyek az ilyen emberre jellemzök. Vé- } \\
\text { gül a terem különböző pontjain elhelyezett, } \\
\text { emberi érzelmeket ábrázoló négy „macis } \\
\text { kártya” közül az elé kell állniuk, amelyik ezt } \\
\text { a szólást, érzelmet mutatja.) } \\
\text { (Zita) - Figyeld meg, mit csinálok a csigá- } \\
\text { val! (A tanító közelít a kezével a csiga felé.) } \\
\text { - Mi történt? Mit csinált a csiga? (Bebújt a } \\
\text { csigaházába) } \\
\text { (Szervezési feladat: a csiga visszakerül a } \\
\text { helyére.) } \\
\text { (Jutka): - Bebújik a csigaházba. Ki hallotta, } \\
\text { hogy ezt nemcsak a csigára, hanem embe- } \\
\text { rekre is mondják? } \\
\text { - Milyen ember az, aki bebújik a csigahá- } \\
\text { zába? Mondjunk tulajdonságokat! (Félénk, } \\
\text { félszeg, ijedős) } \\
\text { - Ha azt látnád, hogy ilyen a társad, hogyan } \\
\text { segíthetnél neki? } \\
\text { - A teremben több helyen láthatjátok a } \\
\text { macis képeinket nagy alakban. Álljatok oda, } \\
\text { amelyik kép azt ábrázolja, hogy bebújt a } \\
\text { maci a csiga házába! } \\
\text { 6. Gryllus Vilmos: Lassan jár a csigabiga } \\
\text { címü dalának eléneklése (Zita) } \\
\text { A gyerekek éneklés közben a helyükre } \\
\text { mennek. } \\
\text { (Zita) - Most búijunk ki a csigaházból las- } \\
\text { san, és miközben ezt tesszük, énekeljük el a } \\
\text { „Lassan jár a csigabiga” címü dalt, és lassan } \\
\text { menjünk is a helyünkre! }\end{array}$ & $\begin{array}{l}\text { szókincsfejlesztés } \\
\text { erkölcsi tulajdon- } \\
\text { ságok tartalmával } \\
\text { kapcsolatos ta- } \\
\text { pasztalatszerzés } \\
\text { tevékenykedtetés } \\
\text { megfigyelés } \\
\text { megbeszélés }\end{array}$ & $\begin{array}{l}\text { frontálisan irá- } \\
\text { nyított egyéni }\end{array}$ & $\begin{array}{l}\text { macis kártya } \\
\text { képe }\end{array}$ \\
\hline
\end{tabular}




\begin{tabular}{|c|c|c|c|c|}
\hline $8 p$ & $\begin{array}{l}\text { 7. Csigával kapcsolatos összetett szavak } \\
\text { alkotása, párosítása a jelentésülket ábrá- } \\
\text { zoló képekkel (Jutka) } \\
\text { (Minden gyerek a csigával kapcsolatos ösz- } \\
\text { szetett szavak elö- vagy utótagját tartalma- } \\
\text { zó szókártyát kap. (Differenciálás: A jobban } \\
\text { olvasók a szavak nehezebb részét kapják, } \\
\text { a gyengébben olvasók a könnyebb felét.) A } \\
\text { feladatuk az, hogy megtalálják a párjukat, } \\
\text { majd megkeressék az általuk megalkotott új } \\
\text { szót ábrázoló képet. Az összetartozó képek } \\
\text { és szókártyák a táblára kerülnek.) } \\
\text { Szervezés: Szókártyák kihelyezése } \\
\text { - Párkeresőss játékot fogunk játszani. Min- } \\
\text { denki egy lefordított szókártyát talál az asz- } \\
\text { talán. Nézzétek meg, és keressetek hozzá } \\
\text { olyan párt, amelyikkel egy új szó keletkezik! } \\
\text { Ha megtaláltátok a szavatok másik felét, } \\
\text { tegyétek a két szókártyát a táblára a hozzá } \\
\text { illő kép alá! } \\
\text { (A szavak: csigatészta, búgócsiga, csigaleves, } \\
\text { csigavonal, csigalépcső, csigaház, csigadísz, } \\
\text { kakaós csiga) } \\
\text { Ellenőrzés: a párok felolvassák a saját } \\
\text { szavukat és megnézzük, hogy jó kép mellé } \\
\text { kerültek-e a szókártyáik. } \\
\text { + Pótfeladat: Csigaforma a müvészetben: } \\
\text { csigaformát ábrázoló képek megfigyelése } \\
\text { (Jutka) } \\
\text { - Mit látunk a képen? Mit lesett el az ember } \\
\text { a csigáktól? } \\
\text { III. Értékelés } \\
\text { Játékos értékelés } \\
\text { (A játék szabálya: csak akkor végezhetik el a } \\
\text { gyerekek az utasítást, ha az a „tanító kéri”.) } \\
\text { J: Jutka néni kéri, hogy állj fel! } \\
\text { J: Tedd fel a kezed magasra! } \\
\text { Z: Zita néni azt kéri, hogy tedd fel a kezed } \\
\text { magasra, ha örülsz annak, hogy új állattal } \\
\text { szaporodott a természetsarkunk! } \\
\text { Z: Tedd le a kezed! } \\
\text { Z: Zita néni kéri, tedd le a kezedet! } \\
\text { J: Jutka néni kéri, guggolj le, ha fegyelme- } \\
\text { zetten dolgoztál az órán! } \\
\text { Z: Zita néni kéri, tapsolj, ha úgy érezted, } \\
\text { hogy figyeltél és szépen dolgoztál az órán! } \\
\text { J: Jutka néni kéri, hagyd abba a tapsot és } \\
\text { Jullj fel! } \\
\text { magad néni kéri, mosolyogj, ha jól érezted } \\
\text { ezen az órán! }\end{array}$ & $\begin{array}{l}\text { ellenőrzés } \\
\text { értékelés } \\
\text { játék }\end{array}$ & $\begin{array}{l}\text { frontális } \\
\text { frontális } \\
\text { frontálisan irá- } \\
\text { nyított egyéni }\end{array}$ & $\begin{array}{l}\text { csigaformát ábrá- } \\
\text { zoló képek }\end{array}$ \\
\hline
\end{tabular}


Az óra a természetsarkunk bővítésének folyamatába épült bele. Egy olyan élőlénnyel találkozhattak először és ismerkedhettek meg a gyermekek testközelből, mely a biológiai sokszínűséget jól szemlélteti.

$\mathrm{Az}$ óra különlegessége a kéttanítós tanulásirányítás volt. Mindketten komplex módon kezeltük a témát, de természetesen - elsősorban - a saját tantárgyunkhoz kapcsolódó fejlesztésért feleltünk. A szervezési feladatok megoldásában kölcsönösen segítettük egymás munkáját.

Az, hogy a gyerekek végig intenzíven dolgoztak, azt bizonyítja, hogy jól választottuk meg a témát és a fejlesztés fókuszait. A tanítók munkamegosztása tevékenységváltással is együtt járt, ami nem zavarta őket, sokkal inkább aktivitásuk ébrentartását eredményezte. (8. és 9. kép)

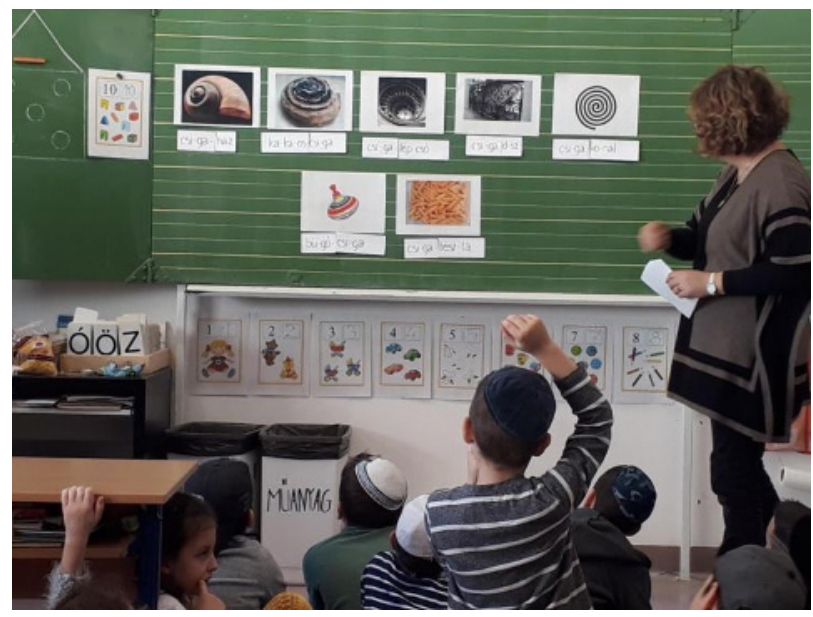

8. kép

Csigákkal kapcsolatos szavak és képük 


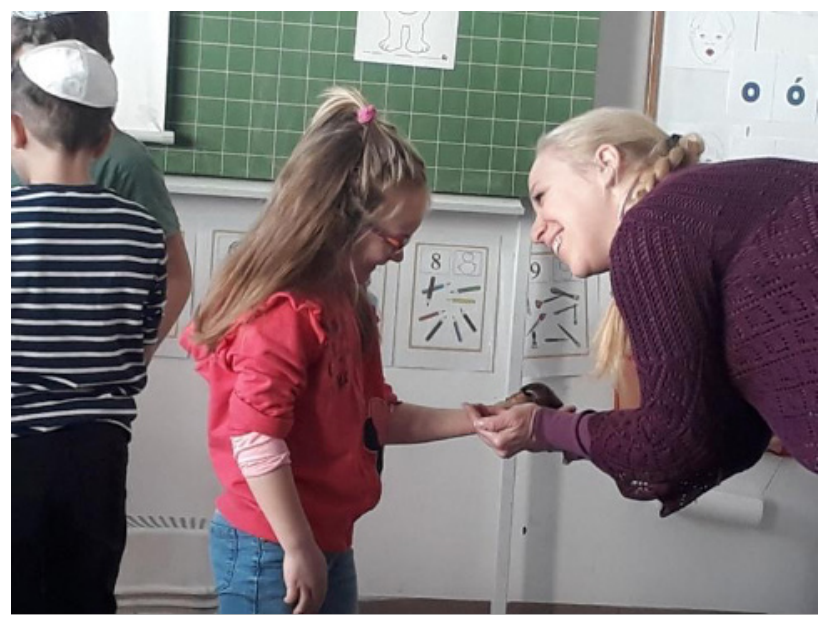

9. kép

Szeretnéd megérinteni?

Az új ismeretszerzést előzetes gyűjtőmunkával (különféle csigaházak kiállítása, rendszerezése), előismeretek mozgósításával és felhasználásával támogattuk. (10. kép)

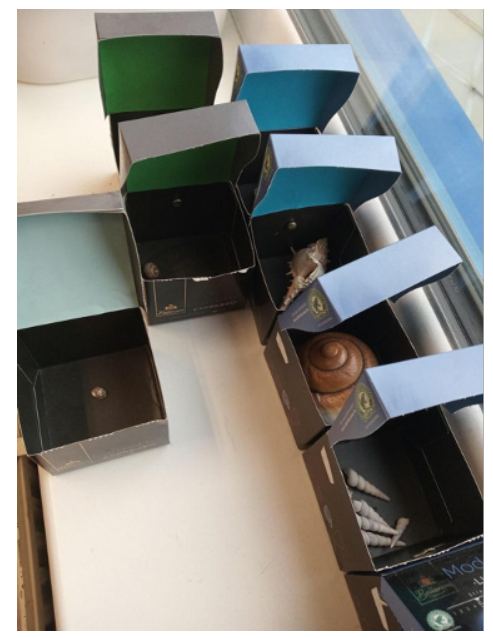

10. kép

Csigaházgyüjtemény 
Gyakoroltuk a csigavonal rajzolását, ez első osztályban a finommotorika fejlesztéséhez különösen fontos. Változatos vizuális eszközökkel is középpontba állítottuk a témát. (11. és 12. kép)
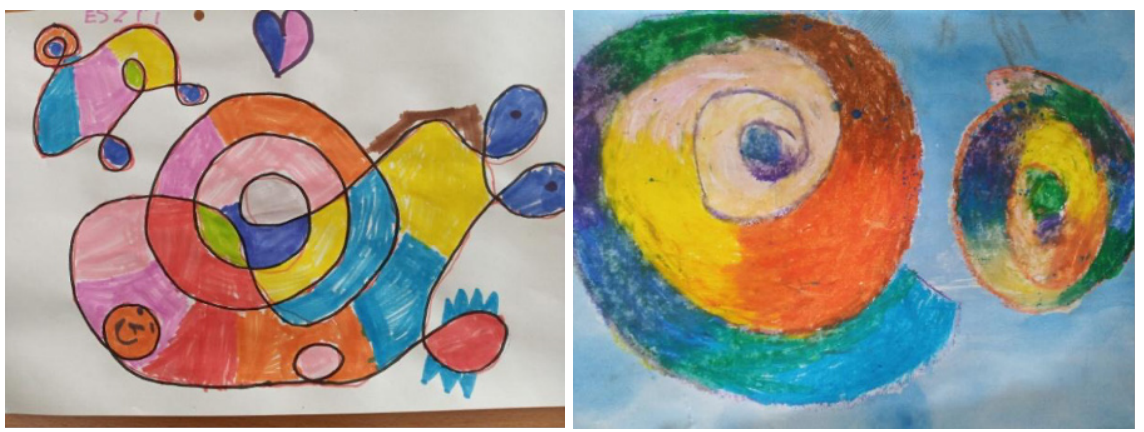

11-12. kép

A csiga megjelenése a rajzokban

Azt tapasztaltuk a tanóra után, hogy a gyerekek érdeklődése megnőtt ezek iránt az élőlények iránt. Örömmel láttuk, hogy többször odamentek a terráriumhoz, és vizsgálták az új állatainkat, meséltek mozgásukkal, táplálkozásukkal kapcsolatos önálló megfigyeléseikről. Azáltal, hogy nevet adunk állatainknak, érzelmileg még közelebb hozzuk őket magunkhoz. (13. kép)

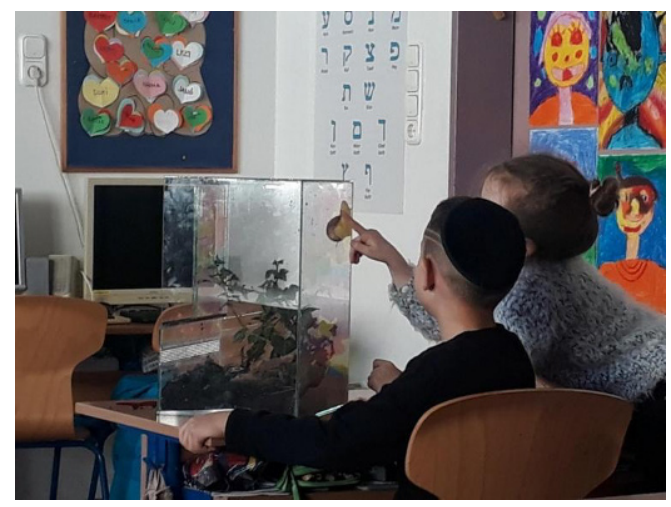

13. kép

Kisállatot tartunk: ismerkedés a csigával

Az ilyen típusú órák nem egyediek, fontosnak tartjuk, hogy több olyan állatot a középpontba állítsunk, amelyek később szintén az osztályunk, ezen belül a természetsarkunk részévé válhatnak (például földigiliszta). 


\section{A szociáliskompetencia-fejlesztő munkánk eredményességének távlatai}

Munkánk sikerességét csak hosszabb távon tudjuk vizsgálni. Szeretnénk, ha 2-3 év múlva elmondhatnánk, hogy a közösség szintjén az osztályban nincs peremhelyzetben lévő gyerek. Fontos, hogy a mindennapi együttélés során azt tapasztalhassuk majd, hogy segítik és elfogadják egymást a gyerekek annak tudatában, hogy valamennyien különbözőek vagyunk. Azt szeretnénk látni, hogy szeretettel és tisztelettel fordulnak egymás felé és nyitottak egymás elfogadása iránt.

Az egyén szintjén azt szeretnénk tapasztalni, hogy fejlödik a pozitív önképük és biztonságban érzi magát mindenki a közösségünkben. Reméljük, hogy a gyerekek környezethez való érzelmi viszonyulása pozitív irányban változik a következő tanévek során.

\section{Irodalom}

Bihariné Krekó, I, (2011). Az óvodai környezeti nevelés módszertana. ELTE Eötvös Kiadó.

Gonda, J. (2014). Paradigmaváltás: módszertani ajánlások a tanulók problémamegoldó gondolkodásának a fejlesztéséhez. Bethlen Gábor Alapkezelő Zrt.

Takács, I. \& Szalai, K. (2017). Állatasszisztált kutatások Kaposvárott - 2011-2016. Gyermeknevelés, 5(2), 18-29.

https://doi.org/10.31074/gyntf.2017.2.18.29

Wilson, E. O. (1984). Biophilia. Harvard University Press.

Zsolnai, A. \& Kasik, L. (2010). A szociális kompetenciák periodikus mérése a TÁMOP 3.1.8.-09/1-2010-0004 azonosítójú kiemelt projekt keretén belül https://www. oktatas.hu/pub_bin/dload/kozoktatas/meresek/unios_tanulmanyok/Szocialis_ kompetencia_tartalmi_keret.pdf (Letöltés: 2020.11. 21.)

*A tanulmányban közölt képek a szülők hozzájárulásával kerültek publikálásra. 


\section{Bauer, Z. \& Gonda, J.}

\section{Let's learn humanity from animals}

The paper is focuesd to help teachers and scholars of primary schools. The authors present a complex program where work of two teachers aim at development of social competences and integration of pupils. The results are presented using theoretical backgrounds and showing best practices of authors.

Keywords: nature, animals, animal assisted development, integration 